\title{
Listening Skills in Learning Process of Indonesian Language for Foreign Speakers at the Tanjungpinang Central Immigration Detention Centre
}

\author{
Dody Irawan ${ }^{1}$, Fabio Testy Ariance Loren ${ }^{2}$, Adinda Umayroh Amalia ${ }^{3}$, Eka Putra \\ Prasetyo $^{4}$, Susan Afriana ${ }^{5}$, Devia Alfira ${ }^{6}$ Natalisha Paramitha Limbong ${ }^{7}$ \\ \{dodyirawan@umrah.ac.id ${ }^{1}$, fabioloren@umrah.ac.id ${ }^{2}$, adinda.amalliia05@gmail.com ${ }^{3}$, \\ ep200100@gmail.com ${ }^{4}$, susanavri17@gmail.com ${ }^{5}$, delpiaalfira@gmail.com ${ }^{6}$, \\ lialimbong13@gmail.com ${ }^{7}$ \}
}

Universitas Maritim Raja Ali Haji, Tanjungpinang, 29124, Indonesia

\begin{abstract}
This study aims to determine the understanding of Indonesian language and to provide basic learning of Indonesian language to detainees at the Tanjungpinang Centre rudimentary through the process of listening skills in order to understand its meaning and facilitate daily communication. Listening skill is one of the basic language skills to help foreign speakers, especially detainees or residents with immigrant status, to learn Indonesian through the Indonesian Language Learning Program for Foreign Speakers (BIPA). This study used case study method and immersion method. Data was collected techniques from this study were in the form of observations, interviews, and discussions between BIPA teachers and the Tanjungpinang Central Immigration Detention Centre regarding information related to the implementation of activities. The results of this study indicate that there were 21 detainees out of the 33 detainees, who show good progress in mastering Indonesian language through the comparison results of pre-test and post-test.
\end{abstract}

Keywords: BIPA, Learning, Listening.

\section{Introduction}

The rapid development in global world and the existence of free markethas a significant impact with the increasing number of foreigners working and studying in Indonesia. Another important aspect that triggers the increasing number of foreigners studying in Indonesia is Indonesia is located in a strategic area and the important position of Indonesia according to other countries because of its role related to politics, economy, culture and tourism. This is proved by data released by the Ministry of Foreign Affairs in 2012 that Indonesian had the fifth most native speakers in the world, as many as 4,463,950 people spread overseas. Then, data in 2009 showed that the local government of Ho Chi Minh City, Vietnam had determined that Indonesian language as the second foreign language after theirlocal language [1]. In the 32nd ASEAN InterPerliamentary Assembly (AIPA) session in 2011, the chairman of the Indonesian House of Representatives, Marzukie Alie, proposed Indonesian language to be used as a work language in subsequent AIPA sessions [2]. These facts support the government efforts to improve the function of Indonesian language into an international language which is being worked on by the Ministry of Education and Culture (Kemendikbud) in collaboration with the Language Development and Development Agency as a service provider institution 
for foreign speakers who are interested in learning Indonesian through the BIPA (Indonesian Language) learning program. for Foreign Speakers). The development of learning Indonesian language can also be a stepping stone for diplomacy that raises the positive image of the Indonesian nation. Currently, the BIPA program is being opened in many regions and even countries that require Indonesian language learning. Certainly, new opportunities are widely open for prospective Indonesian language teachers or Indonesian language teachers. Many peopleare asking how to teach Indonesian language to foreign nationals who do not understand and even illiterate Indonesian? All of the method has been arranged in such a way by the team for preparing BIPA teaching materials, similar with when we learn foreign languages.

BIPA learners are categorized into three levels, namely the beginner (novice), intermediate and advanced levels. In general, there are several aspects of skills that students need and must master in learning language. These skills consist of 4 aspects, namely (1) listening, (2) speaking, (3) reading and (4) writing. Everyone really needs language skills, even though in reality only some people can master all these skills.

According to W.J.S Poerwadarminta in the General Indonesian Dictionary, Listening is hearing (maintaining what people say), listening is an exercise in listening carefully. In the process of listening activities, of course, we find several things that can hinder the receipt of information and there are several methods and learning strategies to overcome such things. The application of Indonesian language as a second language for foreign speakers could not free from mistakes [3]. When the number of mistakes was high, then the achievement level of language learning objectives becomes low. Therefore, it is needed to take action in order to minimize mistake in language. Some factors that might trigger language errors, including the influence of mother tongue, lack of understanding on language and imperfect language teaching [4].

Tanjungpinang Immigration Detention Center is one of the agencies that has a structured function in terms of handling foreigners who violate immigration laws. There are foreign nationals and majority come from Southeast Asian including Vietnam, Myanmar, Thailand, Laos and there are also from Africa, one of which is Nigeria. In order to introduce the basics of Indonesian language through BIPA learning teaching materials that are guided by lecturers and students of the Indonesian Language and Literature Education Study Program, Raja Ali Haji Maritime University, Tanjungpinang, Riau Islands, Indonesia, using observation techniques first to the location and in delivering learning materials using materials. teaching BIPA at the basic level and supported by the results of the pre-test and post-test conducted by foreign nationals to assess the level of understanding of the foreign nationals' listening skills.

This BIPA research had been carried out before. However, researchers had not found any research that evaluates the application of listening skills in basic level BIPA learning. A similar study was carried out by Ganesha Education University students, Yuniarti Rahmalia Hapsari, et al in 2017 entitled Implementation of BIPA Speaking Learning for Class IX Students at Gandhi Memorial Intercontinental School Bali [5]. A second similar study was conducted by Ganesha University Education students, Ni Pt Apita Widya Sari, et al in 2016 entitled Learning Indonesian for Foreign Speakers (BIPA) at the Love Language School, Ubud, Bali [6]. The third similar research was conducted by Malang State University student, Sheilla Arumdyahsari, et al in 2016 entitled Development of Indonesian Language Teaching Materials for Intermediate Foreign Speakers (BIPA). The three studies above have similarities with the research conducted by researchers. The similarity is both of them taught and carried out learning based on BIPA teaching materials but the difference is in the research subjects 
and case studies. Thus, this research is important for innovation in education field, especially learning Indonesian language for Foreign Speakers (BIPA).

\section{Method}

In the learning process of Indonesian language for foreign speakers (BIPA), quantitative research has been carried out. According [7], the approach used in this research is a quantitative approach with a type of one group pre-test post-test. This type of research only one group with a pre-test, after which it is given an explanation of the material and covered with post-test.Based on quantitative research, the data includepre-test and post-test score, observations, and discussions conducted between BIPA (Indonesian for Foreign Speakers) teachers and the Tanjungpinang Immigration Detention Center regarding information related to the implementation of activities. This study focused on acquiring Indonesian language from foreign nationals at the novice level in this learning process. Information on foreign nationals at the Tanjungpinang Central Immigration Detention Center obtained based on research, namely: (1) immigrantsstatus, (2) originating from Southeast Asia, (3) age range 17-50 years, and (4) included in the beginner level (novice) as a BIPA learner.

In the interaction of learning Indonesian language for foreign speakers (BIPA) there are several language choices, namely (1) a single variation of the language used for the beginner level (novice), (2) code switching, and (3) code mixing. The choice of language that is determined is in linguistics subject as its scientific domain. The process of learning Indonesian for foreign speakers (BIPA) used the case study method and the immersion method. Case study method focuses intensively and detail on a case. The case study method generally produces a longitudinal picture, namely the results of collecting and analyzing case data over a period of time.

This study used an observation guide that was carried out in the BIPA learning process, namely language acquisition for foreign nationals. The immersion method was carried out by direct interaction with Indonesian people regarding the real cultural context for a more comprehensive understanding of BIPA learners. In learning by using the immersion method, students experience directly what is the object of their learning. Through the direct experience, the learner becomes more and more aware towards the learning subjects. This method occurs by applying communication in conversation.

There are advantages and disadvantages in this immersion learning method. The advantage of this immersion method is learner could be more comprehensive in studying because students directly experienced something that related to the topic in real situations. While, the lack of this immersion method is related to the allocation of learning time which requires a longer time to understand the learning topic. The application of this method in language learning can support an effective learning process. Besides the linguistic aspect, there is also Indonesian culture aspect that can be learned in this immersion method. They have a mutually supportive relationship with the language acquisition process to foreign nationals, therefore it is suitable to apply in achieving the goals and facilitates learners in the BIPA learning process.

\section{Results and Discussions}


Language skill is crucial for humans in communicating, especially listening skill. This skill allows us to understand and comprehendsomething that we listening to. Listening is the skill of listening carefully to other people's words. Listening skill is the first activities that humans do in the language learning process [6]. Listening skills in learning BIPA at the Tanjungpinang Central Immigration Detention Center are intended to enhance detainees use Indonesian language in communicating with immigration officers and their comrades. The detainees were taught to speak Indonesian to avoid misunderstandings between them. This is the background of this research, so that we can investigate how far the detainees understand Indonesian language properly and correctly.

After observing, we found that the detainees at the Tanjungpinang Central Immigration Detention Center in general still understand Indonesian at a basic level, so we finally decided to provide Indonesian language lessons to the detainees. We had arranged Indonesian language learning for foreign speakers at the Tanjungpinang Central Immigration Detention Center in a simple way to facilitate detainees to understand the material. The material is included in the A1 level which consists of two units, namely; greeting and introducing. Before entering and after completing the learning session, we asked the detainees to answer the pretest and post-test with total 15 questions[8].

\section{A1 Greeting unit}

a. Greeting expression

Greeting expression consists of :
1. Hi
2. Hello
3. Good morning / Selamat pagi
4. Good afternoon / Selamat siang
5. Good evening / Selamat sore
6. Good night / Selamat malam

b. Expression for asking news

The expression of asking for news consists of:

1 . How are you?Apa kabar?

2. How about you?Bagaimana dengan Anda?

c. Gratitude expression

Expressions of gratitude consist of:

1. Thank you

d. Apologies expression

An apology consists of:

1. Sorry

2. Thank you

e. Ask for leave

The expression of ask for leave consists of:

1. ask for leave

2. I have to go

3. See you later

4. Goodbye 
A1 Introductory Unit

a. Read

Read the text below correctly!

1. Hi! My name is Ani. I am 17 years old. I come from Tanjungpinang. I live on Jalan Nusantara, Tanjungpinang. My hobbies are reading and writing.

2. Hi! My name is Budi. I am 18 years old. I come from Batam. I live on Jalan Pemuda, Tanjungpinang. My hobby is taking pictures.

b. Write

Fill in the questions below correctly according to your personal data!

1. Name:

2. Age:

3. Origin:

4. Residence:

5. Hobby:

\section{Listening}

Read the introductory text below, then put a true or false mark on the questions that have been provided according to the introductions that have been listened to earlier!

Hi! My name is Prita Oktavia. I am 16 years old. I come from Tanjungpinang. My hobbies are playing and reading.

Table 1. Answer Column

\begin{tabular}{|c|c|c|}
\hline Statement & True & False \\
\hline \multicolumn{3}{|l|}{ Her name is PritaOktavia } \\
\hline \multicolumn{3}{|l|}{ She comes from Tanjungpinang } \\
\hline 19 years old & & \\
\hline
\end{tabular}

\section{Introduction friends}

Hi, let me introduce, this is my friend!

His name.... His nickname.... His age.., years

He comes from....

He lives in....

His favorite....

Table 2. The Pre-Test and Post-Test results of Detainees at the Tanjungpinang Central Immigration Detention Center

\begin{tabular}{ccccc}
\hline No. & Name & Origin country & Pre Test & Post Test \\
1. & Tram Minn An & Vietnam & $7 / 15$ & $13 / 15$ \\
\hline
\end{tabular}




\begin{tabular}{|c|c|c|c|c|}
\hline 2. & NqujenUan Chon & Vietnam & $5 / 15$ & $3 / 15$ \\
\hline 3. & Dao Mara & Vietnam & $7 / 15$ & $9 / 15$ \\
\hline 4. & Hug Nr EongMuop & Vietnam & $4 / 15$ & $0 / 15$ \\
\hline 5. & Trian Van Utop & Vietnam & $5 / 15$ & $2 / 15$ \\
\hline 6. & Ngugan Van Cinh & Vietnam & $2 / 15$ & $4 / 15$ \\
\hline 7. & Knompna & Laos & $2 / 15$ & $7 / 15$ \\
\hline 8. & ThamVam Ham & Vietnam & $1 / 15$ & $2 / 15$ \\
\hline 9. & NgayenVkaiDuy & Vietnam & $1 / 15$ & $3 / 15$ \\
\hline 10. & TranvanTbang & Vietnam & $1 / 15$ & $14 / 15$ \\
\hline 11. & Mong Duan & Thailand & $5 / 15$ & $7 / 15$ \\
\hline 12. & Nauuyn Van Hilu & Vietnam & $1 / 15$ & $2 / 15$ \\
\hline 13. & Trivin Van Bi & Vietnam & $1 / 15$ & $2 / 15$ \\
\hline 14. & Tran Van Luoc & Vietnam & $2 / 15$ & $10 / 15$ \\
\hline 15. & Nsuyan Van Mbn & Vietnam & $2 / 15$ & $4 / 15$ \\
\hline 16. & Ma Van Cuong & Vietnam & $6 / 15$ & $11 / 15$ \\
\hline 17. & Tian Van Hoai & Vietnam & $6 / 15$ & $10 / 15$ \\
\hline 18. & Le Van TiuongEm & Vietnam & $5 / 15$ & $9 / 15$ \\
\hline 19. & HaynhNtinbHieu & Vietnam & $13 / 15$ & $13 / 15$ \\
\hline 20. & Train Van Hien & Vietnam & $6 / 15$ & $13 / 15$ \\
\hline 21. & Soe The At & Laos & $2 / 15$ & $4 / 15$ \\
\hline 22. & Nyinyinyinag & Laos & $2 / 15$ & $5 / 15$ \\
\hline 23. & NaingSoe & Laos & $9 / 15$ & $11 / 15$ \\
\hline 24. & Nay Aung & Myanmar & $9 / 15$ & $11 / 15$ \\
\hline 25. & Sam Tam Pho & Laos & $0 / 15$ & $0 / 15$ \\
\hline 26. & Pwong Huynh Chon Dung & Vietnam & $5 / 15$ & $7 / 15$ \\
\hline 27. & Ye Thi & Myanmar & $6 / 15$ & $5 / 15$ \\
\hline 28. & SaiAang & Myanmar & $4 / 15$ & $11 / 15$ \\
\hline 29. & Tan Shio & Myanmar & $1 / 15$ & $6 / 15$ \\
\hline 30. & Munfabwti & Thailand & $9 / 15$ & $9 / 15$ \\
\hline 31. & Nyo Van Bay & Vietnam & $5 / 15$ & $9 / 15$ \\
\hline 32. & Dan Tron & Vietnam & $3 / 15$ & $10 / 15$ \\
\hline 33. & TuamDinhPeudns & Vietnam & $3 / 15$ & $10 / 15$ \\
\hline
\end{tabular}

The table above shows that the comparison of pre-test and post-test results from 21 detainees showed good progress in mastering Indonesian. One of the detainees who showed remarkable progress in mastering the Indonesian language that had been taught was on behalf of Tranyan Tbang who came from Vietnam with a comparison between the results of the pre test and post test of 12 points and the detainee who experienced a setback in understanding the Indonesian language being taught was Hug Nr Eong Muop with a comparison between the results of the pre test and post test of -4 points. This shows that the teaching materials that have been made by researchers have been successfully applied in learning Indonesian language for foreign speakers or detainees at the Tanjungpinang Immigration Detention Center. 


\section{Conculsions}

BIPA learners are categorized into three levels, namely the beginner (novice), intermediate (intermediate) and advanced (advanced) levels. In general, in learning a language, there are several aspects of skills that students need and must master. These skills consist of 4 aspects, namely (1) listening, (2) speaking (3) reading and (4) writing. Listening skills aspects are basic things to understand a language. Based on this, the researchers tried to investigate the relationship between the role of listening skills in the Indonesian language learning process for Basic Level Foreign Speakers (BIPA). The results of this study, indicate that as many as 21 detainees comparing the results of the pre-test and post-test showed good progress in mastering Indonesian. One of the detainees who showed remarkable progress in mastering the Indonesian language that had been taught was on behalf of Tranyan Tbang who came from Vietnam with a comparison between the results of the pre test and post test of 12 points and the detainee who experienced a setback in understanding the Indonesian language being taught was Hug Nr Eong Muop with a comparison between the results of the pre test and post test of -4 points. This shows that the teaching materials that have been made by researchers have been successfully applied in learning Indonesian for detainees at the Tanjungpinang Immigration Detention Center.

\section{References}

[1] Muliastuti, Liliana.: Bahasa Indonesia bagi Penutur Asing. Yayasan Pustaka Obor, Jakarta (2019)

[2] Pimpinan. Ketua DPR Tetap Perjuangkan Bahasa Indonesia Jadi Bahasa Resmi AIPA. (2011) Diakses pada 25 Juni 2021.

https://www.dpr.go.id/berita/detail/id/3095/t/Ketua+DPR+Tetap+Perjuangkan+Bahasa+Indonesi a+Jadi Bahasa+Resmi+AIPA

[3] Saddhono, K., Slamet, St.Y. Meningkatkan Keterampilan Berbahasa Indonesia. Karya Putra Darwati, Bandung (2012)

[4] Maharani, Tisa., \& Endang, Setiyo Astuti: Pemerolehan Bahasa Kedua dan Pengajaran Bahasa dalam Pembelajaran BIPA.Jurnal Bahasa Lingua Scientia 1(1):122-126 (2018)

[5] Hapsari, Yuniarti Rahmalia, I. M: Pelaksanaan Pembelajaran BIPA Siswa Kelas IX di Gandhi Memorial Intercontinental School Bali. e-Journal Universitas Pendidikan Ganesha, 6 (1), 2-5. (2016)

[6] Sari, Ni Apita Widya, I.M. PembelajaranBahasa Indonesia bagi Penutur Asing (BIPA) di Sekolah Cinta Bahasa, Ubud, Bali. e-Journal Prodi Pendidikan Bahasadan Sastra Indonesia, Undiksha5(3):2-5 (2016)

[7] Sugiyono. Metode Penelitian Pendidikan (Pendekatan Kuantitatif, Kualitatif, dan R\&D). Bandung: Alfabeta (2015)

[8] Pusat Pengembangan Strategi, Diplomasi Kebahasaan, Badan Pengembangan dan Pembinaan Bahasa. Sahabatku Indonesia: Tingkat A1. Pusat Pengembangan Strategi, Diplomasi Kebahasaan, Badan Pengembangan dan Pembinaan Bahasa. Jakarta (2016) 